\title{
Is Human Capital Related to Voluntary Turnover in U.S. State Governments? Evidence from the State of Oklahoma
}

\author{
Andrew Wesemann \\ Department of Public Administration and Policy Analysis, \\ Southern Illinois University Edwardsville, \\ 3128 Alumni Hall, Edwardsville, IL 62026 \\ Tel: 1-618-650-3762Ｅ-mail: awesema@siue.edu
}

Received: January 16, 2020 Accepted: February 9, 2020 Published: February 22, 2020

doi:10.5296/jpmr.v6i1.16253ＵRL: https://doi.org/10.5296/jpmr.v6i1.16253

\begin{abstract}
Building and retaining human capital stock is critical for organizational success and survival. These two practices, however, may inadvertently be at odds with one another. That is, as organizations seek to increase their human capital stock, through both internal and external strategies, they may also unintentionally increase their risk of voluntary turnover. Research has found support for this relationship in the private sector, yet empirical evidence for such a correlation among public sector organizations is nonexistent. This article, therefore, contributes to the understanding of whether the postulated relationship between human capital and voluntary turnover is generalizable to public sector entities, specifically focusing on U.S. state government. Using longitudinal workforce data from the State of Oklahoma, results of econometric analyses demonstrate that this organizational phenomenon transcends sector boundaries.
\end{abstract}

Keywords: public sector turnover, human capital, employee mobility

\section{Introduction}

Scholars and practitioners widely assert that employee human capital is a key organizational asset that should be strategically sought after, developed, and retained in order to achieve sustained competitive advantages (McGregor, 1991; Boone, Eckardt, Lepak, \& Boselie, 2018). Human capital is typically defined as the knowledge, skills, and abilities embedded within individuals as innate characteristics, or acquired and developed through education, training, and experience (Wei, 2015). As such, research suggests organizations that employ 
strategic human capital management approaches (e.g., acquisition, development, and retention initiatives) may experience substantial performance related gains. Conversely, organizations that fail to recruit and retain sufficient levels of human capital can experience considerable consequences that may threaten their success and survival (Condrey, 2010).

Not surprisingly, then, employee turnover has been an ongoing concern among public managers for decades, given its theoretical linkages to high organizational costs and adverse performance outcomes (Grissom, Nicholson-Crotty, \& Keiser, 2012). More recently, however, this issue has grown in importance and urgency as the U.S. labor force faces what many have termed the human capital crisis (Liebowitz, 2011; Lewis, 1991). Research clearly shows that a tremendous proportion of the U.S. workforce will retire within the next several years, leaving a significant disparity in the number of employees prepared to fill these position vacancies. In particular, the baby boomer generation will have increased their relative share of the U.S. population from 26.4 percent in 1990 to 36.6 percent by the end of 2020 (Toosi, 2012). Put differently, 3.6 million individuals are projected to leave the labor force by 2020 , mainly due to aging and retirement, while only 2.8 million workforce entrants are projected to fill these vacancies, and research suggests that this trend will be perpetuated in the decades to come (Toossi, 2012; Toossi, 2016).

Thus, as the human capital crisis fully matures, organizational competition within and across sectors for valuable human capital will be exacerbated. Here, public sector organizations are likely to be placed at a distinct disadvantage, because of their limited fiscal resources and rather inflexible human resource policies and practices (Thom \& Reilly, 2015). As a consequence, it plausible that a greater proportion of labor force participants and entrants will be lured toward private sector employment.

Perhaps even more concerning, however, is that research on employee mobility suggests a positive relationship exists between human capital levels and voluntary turnover. That is, as employees grow and develop their human capital through various mechanisms, the risk of them seeking more advantageous employment opportunities increases, because they become more attracted to competing organizations within the labor force (Flaherty Manchester, 2012; Wei, 2015). Importantly, however, this research is almost exclusively limited to the private sector and focuses on employee mobility between firms. Therefore, the question of whether this relationship holds in federal, state, and local government contexts remains largely unanswered as there is currently no empirical evidence for this relationship in the public sector literature.

Hence, this study contributes to the extant scholarship by investigating whether human capital levels influence voluntary turnover in the public sector, specifically focusing on state government. The relationship between human capital and voluntary turnover is of particular interest, because high levels of voluntary turnover have been shown to impose negative effects on various dimensions of organizational outcomes (Grissom et al., 2012; Llorens \& Stazyk, 2011). This is especially important, given the inevitable attrition that will occur through the aforementioned workforce exists. Thus, in order to remain competitive and efficient, organizations must consider the various factors that will influence employee mobility and, in turn, respond accordingly. As such, this study explores the degree to which 
human capital levels increase voluntary employee turnover.

To examine the relationship between human capital and voluntary employee turnover, I analyze workforce data collected by the State of Oklahoma's Human Capital Management (HCM) Division of the Office of Management and Enterprise Services (OMES). The following section of this research reviews the literature on human capital and employee mobility. I then turn to a brief discussion of the implications of voluntary turnover on organizational performance in the public sector. Subsequently, I highlight this study's theoretical expectations, which link higher levels of human capital to greater voluntary turnover among employees. Next, I explicate the data and measures used, as well as the results of econometric analyses. This research concludes with a discussion of the implications of the results for public sector scholars and practitioners.

\section{Literature Review}

\subsection{Human Capital and Voluntary Turnover}

Human capital consists of knowledge, skills, and abilities that are innately embedded within individuals (McGregor, 1991), and theory asserts that it can also be cultivated through various managerial inputs, such as training and continuing education (Green \& Roberts, 2012; Herremans \& Isaac, 2004). In addition, a substantial body of literature suggests that human capital is associated with positive organizational performance outcomes at multiple levels (McGregor, 1991; Becker, 1964; Ndinguri, Prieto, \& Machtmes, 2012; Hollenbeck \& Jamieson, 2015; Mawdsley \& Somaya, 2016). Logically, then, organizations are incentivized to acquire and develop human capital stock in order to achieve competitive advantages and optimal performance levels.

Though scholarship generally acknowledges that acquiring and developing human capital can prove advantageous, under certain contexts, private sector focused research has developed suggesting that unintended organizational consequences can arise as well. In particular, as organizations grow their human capital stock, through both internal and external strategies, they may also inadvertently increase their risk of employee turnover (Mawdsley \& Somaya, 2016). It is important to emphasize, however, the literature linking human capital to employee mobility is exclusively private sector focused. Thus, in order to develop a solid theoretical framework, this research must rely on human capital and employee mobility theory that is largely rooted in private sector scholarship.

Nonetheless, the literature demonstrates that employees, in addition to organizations, stand to benefit from acquiring and developing their own human capital. By doing so, employees increase their own personal value within their employing organization, as well as in the general workforce, while simultaneously increasing their likelihood of internal and external job mobility (Wei, 2014; Wright, Tartari, Huang, Di Lorenzo, \& Bercovitz, 2018; Flaherty Manchester, 2012). As a result, research suggests that employees have become increasingly deliberate in managing their careers and developing their own human capital (Mawdsley \& Somaya, 2016). Indeed, the monetary rewards and other career benefits associated with positions that necessitate higher levels of human capital provide significant incentives for individuals to gravitate toward such positions, either internally or externally (Lepak \& Snell, 
1999).

Following both research streams highlighted thus far, Shaw, Park, and Kim (2013) argue that although the literature demonstrates investment in human capital can produce positive and significant performance outcomes, it has failed to demonstrate such investments surpass the costs that occur through voluntary turnover. In other words, the authors suggest that the performance related advantages of building human capital may not be symmetric with the performance related disadvantages of human capital loss (Shaw et al., 2013). Undoubtedly, this research holds substantial implications for organizational strategy in terms of determining optimal levels of human capital investment.

Although some scholars argue that it is insufficient to examine the relationship between aggregate human capital and employee job mobility; instead, research must differentiate between general human capital and organization-specific (i.e., firm-specific) human capital (Campbell, Coff, Kryscynski, 2012). Here, the literature argues that organization-specific human capital is acquired through a dual investment by the organization and employee in obtaining competencies that are unique to the organization and, as such, are not easily transferable. Thus, the likelihood that either the employee or organization will terminate their relationship is lower (Campbell, Coff, Kryscynski, 2012; Hashimoto, 1981). In contrast, general human capital consists of universal competencies and skills that are generally sought after in the labor force and easily transferable from one organization to another (Flaherty Manchester, 2012).

More recent scholarship, however, contends that organization-specific and general human capital are not mutually exclusive and therefore cannot be analyzed separately. For instance, Morris, Alvarez, Barney, and Molloy (2017) suggest that an employee's willingness to invest in firm-specific human capital acts as a signal of general human capital. Thus, general human capital is observed through and employee's willingness and ability to make firm-specific investments that are largely discretionary and beyond what is required of their position (e.g., developing teamwork skills, learning organizational software, etc.). As such, it is undoubtedly difficult to analyze these two forms of human capital separately as substantial overlap exists (Morris et al., 2017).

But regardless of whether one is interested in examining the effects of organization-specific or general human capital, measuring both constructs can prove to be problematic, since human capital attributes (i.e., knowledge, skills, and abilities) are not overtly tangible. As a result, researchers and practitioners have relied on various constructs to serve as indicators of human capital levels in employees and organizations. Here, research shows that organizations typically seek human capital measured in terms of education level, training, and prior workforce experience (i.e., prior positions held). These characteristics are significant determinants of what types of positions and individual will fill (Delery, \& Roumpi, 2017; Wei, 2014). In essence, then, organizations naturally build their human capital stock as employees gain ongoing professional experience. In addition, human capital levels can be further developed through strategic human capital management practices, such as training, professional development, continuing education, and mentorship initiatives (Delery \& Roumpi, 2017). 
But despite the competing theoretical frameworks and measurement challenges surrounding employee human capital, Mawdsley and Somaya (2016) generally conclude, through an expansive review of the private sector employee mobility literature, that human capital holds a significant and positive relationship with voluntary turnover. Assuredly, such a relationship poses substantial implications for organizational performance and warrants further empirical investigation in the public sector, given the consequences that are associated with human capital loss through voluntary turnover (Shaw et al., 2013).

\subsection{The Effects of Voluntary Turnover}

The private sector literature concerned with employee turnover generally provides strong empirical support for the detrimental impacts of employee turnover on organizational performance. However, empirical investigation of this relationship in the field of public management is lacking (Grissom, Viano, \& Selin, 2015). In particular, public management scholarship on employee turnover can be segmented into two general research streams. At one end, a large body of research has developed, which examines various factors that influence employee turnover. Here, research typically considers either supply-side factors, such as employee job satisfaction, or demand-side factors, such as managerial retention strategies (Grissom et al., 2015). Regardless of which side one considers, however, only performance related implications are conceived based on theoretical perspectives rather than empirical evidence through this form of research. In contrast, the second research stream is quite limited as only two studies empirically test the relationship between public sector performance and turnover, which is treated as the independent variable of interest (Lee, 2018; Meier \& Hicklin, 2008).

Nevertheless, in general, management research has primarily focused on the effects of turnover in terms of either financial or less tangible knowledge-based and productivity costs (Bertelli, 2007; Llorens \& Stazyk, 2011). The financial costs associated with employee turnover are generally quantified through additional recruitment and retention costs, as well as training and development costs expended by organizations (Lewis, 1991). In contrast, the less tangible knowledge-based and productivity costs associated with high employee turnover consist of human resource costs (McGregor, 1991; Balfour \& Neff, 1993), the time needed by replacements to attain the productivity levels that were achieved prior to the turnover event (Hayes, 2004), declining employee job satisfaction and morale, and low organizational commitment (Ban, Drahnak-Faller, \& Towers, 2003; Perry, 2004; Rainey, 2003).

Before concluding, however, it is worth noting that some public sector research hypothesizes that employee turnover can be positively associated with organizational performance. Though there is only evidence for such a relationship with involuntary turnover and transfers, not voluntary turnover (Lee, 2018). Perhaps not surprisingly, it is the unanticipated loss of human capital that imposes organizational consequences (Shaw et al., 2013).

Thus, on the whole, the literature shows that the aforementioned effects of voluntary turnover can prove detrimental to organizational performance. In particular, when voluntary turnover occurs, management must reallocate substantial resources to curtail the monetary and productivity costs associated with attrition instead of using them to achieve the primary 
mission and objectives of the organization (Bertelli, 2007; Grissiom et al., 2012; Llorens \& Stazyk).

\subsection{Contribution}

Taken together, the literature on human capital and voluntary turnover provides a strong theoretical framework in which increasing employee human capital levels may inadvertently result in higher voluntary turnover rates, thus generating negative implications for organizational performance. But despite establishing a strong theoretical foundation for the postulated relationships, scholarship has not provided supporting empirical evidence among public sector organizations. Therefore, it is inappropriate to assume that this relationship is generalizable across sectors and levels of government. Clearly, empirical research in this area is necessary due to its potential to inform organizational and managerial strategy. This is perhaps more important than ever, given the looming human capital crisis in the U.S. labor force. Therefore, this study aims to contribute to the extant literature by empirically testing the relationship between human capital levels and voluntary turnover rates among employees within a state government context.

\section{Data and Variables}

In order to empirically examine whether public sector employee human capital is positively and significantly related to voluntary turnover, specifically at the state level of government, this research uses data from the State of Oklahoma's Human Capital Management (HCM) division of the Office of Management and Enterprise Services (OMES). Employee turnover and demographic data for the entire State of Oklahoma's government workforce has been collected through the OMES system each fiscal year (FY) from 2013 to 2018 and parsed out for each agency. The data for each FY was aggregated in order to perform a longitudinal analysis. Descriptive statistics for this study's analytic sample are provided in Table 1.

Table 1. Descriptive Statistics

\begin{tabular}{|c|c|c|c|c|c|c|c|}
\hline & $\begin{array}{l}2013 \\
\text { Mean } \\
(\mathrm{SD})\end{array}$ & $\begin{array}{l}2014 \\
\text { Mean } \\
(\mathrm{SD})\end{array}$ & $\begin{array}{l}2015 \\
\text { Mean } \\
(\mathrm{SD})\end{array}$ & $\begin{array}{l}2016 \\
\text { Mean } \\
(\mathrm{SD})\end{array}$ & $\begin{array}{l}2017 \\
\text { Mean } \\
(\mathrm{SD})\end{array}$ & $\begin{array}{l}2018 \\
\text { Mean } \\
(\mathrm{SD})\end{array}$ & $\begin{array}{l}\text { Total } \\
\text { Mean } \\
\text { (SD) }\end{array}$ \\
\hline Voluntary Turnover & $\begin{array}{l}0.129 \\
(0.121)\end{array}$ & $\begin{array}{l}0.128 \\
(0.123)\end{array}$ & $\begin{array}{l}0.128 \\
(0.133)\end{array}$ & $\begin{array}{l}0.141 \\
(0.157)\end{array}$ & $\begin{array}{l}0.131 \\
(0.113)\end{array}$ & $\begin{array}{l}0.143 \\
(0.159)\end{array}$ & $\begin{array}{l}0.133 \\
(0.135)\end{array}$ \\
\hline$\%$ Officials/Administrator & $\begin{array}{l}0.172 \\
(0.207)\end{array}$ & $\begin{array}{l}0.164 \\
(0.192)\end{array}$ & $\begin{array}{l}0.173 \\
(0.194)\end{array}$ & $\begin{array}{l}0.176 \\
(0.193)\end{array}$ & $\begin{array}{l}0.170 \\
(0.190)\end{array}$ & $\begin{array}{l}0.173 \\
(0.187)\end{array}$ & $\begin{array}{l}0.171 \\
(0.193)\end{array}$ \\
\hline$\%$ Professionals & $\begin{array}{l}0.427 \\
(0.256)\end{array}$ & $\begin{array}{l}0.430 \\
(0.260)\end{array}$ & $\begin{array}{l}0.447 \\
(0.263)\end{array}$ & $\begin{array}{l}0.444 \\
(0.255)\end{array}$ & $\begin{array}{l}0.451 \\
(0.265)\end{array}$ & $\begin{array}{l}0.453 \\
(0.264)\end{array}$ & $\begin{array}{l}0.442 \\
(0.260)\end{array}$ \\
\hline \%Technicians & $\begin{array}{l}0.047 \\
(0.103)\end{array}$ & $\begin{array}{l}0.039 \\
(0.085)\end{array}$ & $\begin{array}{l}0.040 \\
(0.088)\end{array}$ & $\begin{array}{l}0.044 \\
(0.098)\end{array}$ & $\begin{array}{l}0.045 \\
(0.104)\end{array}$ & $\begin{array}{l}0.048 \\
(0.102)\end{array}$ & $\begin{array}{l}0.044 \\
(0.097)\end{array}$ \\
\hline$\%$ Protective Service Worker & $\begin{array}{l}0.066 \\
(0.173)\end{array}$ & $\begin{array}{l}0.068 \\
(0.176)\end{array}$ & $\begin{array}{l}0.068 \\
(0.177)\end{array}$ & $\begin{array}{l}0.067 \\
(0.176)\end{array}$ & $\begin{array}{l}0.062 \\
(0.156)\end{array}$ & $\begin{array}{l}0.059 \\
(0.153)\end{array}$ & $\begin{array}{l}0.065 \\
(0.169)\end{array}$ \\
\hline
\end{tabular}


$\%$ Paraprofessionals

$\%$ Office/Clerical

$\%$ Skilled Craft

$\%$ Service Maintenance

Average Years of Service

Average Age

$\%$ Traditional

$\%$ Boomer

$\%$ GenX

$\%$ Millennials

$\%$ Female

$\%$ Minority

$$
\begin{array}{lllllll}
0.037 & 0.040 & 0.041 & 0.046 & 0.044 & 0.041 & 0.041
\end{array}
$$$$
\begin{array}{lllllll}
0.079 & (0.091) & (0.089) & (0.094) & (0.089) & (0.083) & (0.087)
\end{array}
$$

$\begin{array}{lllllll}0.182 & 0.177 & 0.191 & 0.187 & 0.196 & 0.186 & 0.187\end{array}$

$\begin{array}{lllllll}0.149) & (0.158) & (0.165) & (0.164) & (0.171) & (0.167) & (0.162)\end{array}$

$\begin{array}{lllllll}0.016 & 0.014 & 0.012 & 0.011 & 0.009 & 0.006 & 0.011\end{array}$ $\begin{array}{llllllll}(0.063) & (0.059) & (0.050) & (0.049) & (0.041) & (0.022) & (0.049)\end{array}$

$\begin{array}{lllllll}0.023 & 0.021 & 0.023 & 0.022 & 0.018 & 0.021 & 0.021\end{array}$

$\begin{array}{llllllll}0.067) & (0.060) & (0.067) & (0.064) & (0.056) & (0.065) & (0.063)\end{array}$

$\begin{array}{lllllll}12.237 & 12.354 & 48.384 & 12.697 & 12.779 & 12.571 & 18.577\end{array}$

$\begin{array}{lllllll}(4.571) & (4.745) & (4.970) & \text { (4.853) } & \text { (4.945) } & \text { (4.758) } & \text { (14.271) }\end{array}$

$\begin{array}{lllllll}48.409 & 48.621 & 12.273 & 48.695 & 48.817 & 48.663 & 42.500\end{array}$

$\begin{array}{lllllll}(5.500) & (5.780) & (4.652) & (4.589) & (4.690) & \text { (5.069) } & \text { (14.539) }\end{array}$

$\begin{array}{lllllll}0.044 & 0.025 & 0.029 & 0.021 & 0.015 & 0.012 & 0.025\end{array}$

$\left.\begin{array}{lllllll}0.082 & (0.068) & (0.072) & (0.053) & (0.040) & (0.037) & (0.062\end{array}\right)$

$\begin{array}{lllllll}0.570 & 0.465 & 0.435 & 0.417 & 0.406 & 0.373 & 0.445\end{array}$

$\begin{array}{lllllll}(0.209) & (0.213) & (0.207) & (0.192) & (0.180) & (0.193) & (0.209)\end{array}$

$\begin{array}{lllllll}0.278 & 0.343 & 0.349 & 0.379 & 0.371 & 0.378 & 0.349\end{array}$

$\begin{array}{llllllll}(0.175) & (0.186) & (0.191) & (0.190) & (0.172) & (0.183) & (0.186)\end{array}$

$\begin{array}{lllllll}0.108 & 0.140 & 0.181 & 0.183 & 0.208 & 0.228 & 0.174\end{array}$

$\begin{array}{lllllll}(0.119) & (0.132) & (0.142) & (0.131) & (0.140) & (0.154) & (0.142)\end{array}$

$\begin{array}{lllllll}0.553 & 0.562 & 0.565 & 0.569 & 0.566 & 0.593 & 0.568\end{array}$

$\begin{array}{lllllll}(0.223) & (0.223) & (0.211) & (0.201) & (0.215) & (0.221) & (0.215)\end{array}$

$\begin{array}{lllllll}0.158 & 0.166 & 0.166 & 0.172 & 0.180 & 0.182 & 0.171\end{array}$

$\begin{array}{llllllll}(0.116) & (0.125) & (0.125) & (0.127) & (0.138) & (0.135) & (0.128)\end{array}$

\subsection{Dependent Variable}

The dependent variable used in this research, voluntary turnover, is calculated as the total number of willing employee separations from an agency divided by the agency's beginning FY employee headcount (OMES, n.d.). Further, due to the structure of the data and the nature of this study's dependent variable, agencies represent the unit of analysis, not individual employees.

\subsection{Independent Variables}

Public management scholarship suggests that employees generally fall into broad position categories, which implicitly necessitate varying degrees of human capital (McGregor, 1991). For instance, employees that hold more 'professional' positions (i.e., positions that require advanced expertise, knowledge, education, etc.), typically have higher levels of human capital than those in entry level positions (Wayne, Liden, Kraimer, \& Graf, 1999). As such, this research uses position categories provided in OMES HCM data sets, which are derived 
from the affirmative action and equal employment opportunity guidelines, as proxies for varying degrees of human capital.

Employee positions are placed into eight different job categories: 1) officials and administrators, 2) professionals, 3) technicians, 4) protective service workers, 5) paraprofessionals, 6) administrative support, 7) skilled craft workers, and 8) service maintenance (see the Appendix for specific descriptions of each job category). Given the aforementioned research, I argue that each of these job categories tacitly serve as measures of different levels of employee human capital. Here, it is likely that employee position categories fall along a continuum, with 'official and administrators,' 'professionals' and 'paraprofessionals' possessing the highest levels of human capital, relative to the other position categories as these positions necessitate advanced competencies and skill sets.

\subsection{Controls}

When assessing the relationship between human capital and voluntary turnover it is, of course, necessary to include other potential influences on voluntary turnover. In order to do so, this analysis includes a measure of average years of service, average agency age, and generational indicators (i.e., traditional, boomers, generation Xers, and millennials). I expect that average agency years of service and age will be positively associated with voluntary turnover, due to a greater likelihood that they will retire. Similarly, I expect generational variables that represent an older age group (e.g., Traditional) will be positively associated with voluntary turnover due to the likelihood of retirement, as well. Finally, I control for the percentage of female and minorities in each agency, although I do not have a clear expectation for the direction of the impact of these controls.

\section{Methods}

Because this study examined panel data, a fixed effects econometric method was employed. This approach offers two notable advantages compared to a cross sectional data method. Specifically, a fixed-effects method addresses the issue of revere causality through the use of time lagged human capital variables (i.e., position classifications) and controlling for other potential factors. Additionally, a fixed effects method reduces the risk of omitted variable bias by controlling for unobservable state agency characteristics and other contexts across time (Lee, 2018).

Before moving on to the results, it is important to note that the panel dataset used in this analysis was unbalanced. However, this issue is typical when examining organizations that have missing years for at least some cross-sectional units in the sample and does not significantly affect the model (Wooldridge, 2009). Further, this analysis reports robust standard errors in order to correct for diagnosed heteroscedasticity.

\section{Results}

The results for the fixed effects model testing the relationship between human capital indicators and voluntary turnover are reported in table 2 . The model predicted 8.3 percent of the variation of voluntary turnover in state agencies and the F-statistic was statistically significant. Results show that of the eight proxies used as measures of human capital, only 
agency percentage of professional and paraprofessional positions were statistically significant and positively associated with voluntary turnover. Thus, the coefficients indicate that a one-point increase in the percentage of professional and paraprofessional employees in an agency results in 0.196 and 0.344 increase in the percentage of voluntary turnover, respectively. Substantively, the findings suggest that a one unit increase in the agency percentage of employees in professional and paraprofessional positions is associated with approximately a $1 / 5$ and $1 / 3$ percentage increase in voluntary turnover in the 127 agencies examined here. All other position classification percentages (official/administrators, technicians, protective service workers, office/clerical, skilled craft, and service maintenance) were not statistically significant.

Notably, the percentage of 'officials/administrators' variable was not significantly related to voluntary turnover, despite my prior proposition that such positions require high levels of human capital. However, it is possible that is because positions classified as officials and administrators are among the highest within the state government and represent employees that are at the peak of their careers. As such, these employees may be less inclined to seek employment elsewhere.

Furthermore, this study's control variables did not completely conform to my theoretical expectations. While the percent of traditional generations was statistically significant and positively associated with voluntary turnover, average age and years of service were significant and negatively associated with voluntary turnover. One possible explanation for these findings may simply be that the traditional generation variable serves as an indicator of retirement likelihood; whereas, average agency age and years of service are in fact indicators of job satisfaction, thus decreasing employee desire to seek alternative employment. Lastly, although I did not have a theoretical expectation for the controls for gender and minority status, it is important to note that the percentage of female and minority controls were statistically significant and positively associated with turnover. Here, it is plausible that this may be a function of workforce climates that historically have been less conducive to underrepresented employees (Berdahl \& Moore, 2006; Plaut, Thomas, \& Hebl, 2014).

Table 2. Fixed Effect Results for voluntary Turnover

\begin{tabular}{lcc}
\hline Variables & Coefficient & Robust SE \\
\hline \% Officials/Administrator & 0.110 & 0.147 \\
\% Professionals & $0.196^{*}$ & 0.117 \\
\% Technicians & 0.133 & 0.228 \\
\% Protective Service Worker & 0.260 & 0.181 \\
\% Paraprofessionals & $0.344^{* *}$ & 0.147 \\
\% Office/Clerical & -0.046 & 0.146 \\
\% Skilled Craft & -0.187 & 0.329 \\
\% Service Maintenance & -0.125 & 0.227 \\
Average Years of Service & $-0.009 * * *$ & 0.003 \\
Average Age & $-0.009 * * *$ & 0.003
\end{tabular}


$\%$ Traditional

$\%$ Boomer

$\%$ GenX

$\%$ Millennials

$\%$ Female

$\%$ Minority

Constant

Number of Observations

Number of Agencies

$\mathrm{R}^{2}$

$\mathrm{F}$

$*_{\text {indicates }} \mathrm{p}<0.10 ; * *$ indicates $\mathrm{p}<0.05 ; * * *$ indicates $\mathrm{p}<0.01$

\section{Discussion and Conclusion}

This article contributes to the extant literature by testing the generalizability of human capital and job mobility theory for public sector organizations, specifically at the state government level. Using position categories as proxy variables for differing levels of human capital among the State of Oklahoma's government agencies, the study finds evidence that positions with higher levels of human capital are positively associated with voluntary turnover. More specifically, employees that hold professional and paraprofessional positions, which required advanced levels of education, on-the-job experience, and formal training and development, pose a greater likelihood of voluntary turnover. As mentioned, official and administrator positions did not hold a significant positive relationship with turnover, despite theoretically possessing the highest levels of human capital. Although this result did not conform to the initial theoretical expectations, further analysis provides one possible explanation. Specifically, since these employees have reached the highest echelons of their respective units and have likely reached the peak of their career, it is reasonable to argue that they are disinterested in making another position change.

At first blush, the literature and findings presented through this research paint a somewhat discouraging picture for organizations and managers. While practitioners certainly have good reason to develop the human capital within their respective workforce, they may not see the return on investment if employees are motivated to leave once a certain competency level has been attained. Fortunately, management research on factors influencing and deterring turnover is robust and prescribes a multitude of strategies and practices that can be used to curtail voluntary turnover. More recently, scholarship has called for the use of strategic human capital management (SHCM), which is a comprehensive approach that simultaneously reduces workforce volatility and facilitates performance gains by embracing innovative practices, such as recruitment and retention plans (Condrey, 2010; Green \& Roberts, 2012). For instance, research indicates that tuition reimbursement programs positively associate with 
employee retention among employees holding professional positions (Flaherty Manchester, 2012).

On the whole, then, while this study provides empirical support for the relationship between human capital and voluntary turnover, it also implicitly provides validation for the use of proactive managerial strategies that prevent potential external employee mobility. These results undoubtedly have important implications for public managers, especially given the significant consequences associated with the loss of human capital. As such, public sector organizations may be well served by investing in SHCM initiatives that target this specific employee demographic.

Still, while the results discussed above are of substantial importance, more research is needed to draw confident conclusions from them. First, future research should test the relationship between human capital and voluntary turnover among federal and local entities, as well. Until empirical research is expanded to these organizations, the generalizability of this relationship in the public sector remains limited in scope. Second, future research should also employ longitudinal analysis at the individual level, rather than the agency level. Third, while I argue that using position categories as proxies for human capital levels is theoretically sound, greater insight could be drawn from a more conclusive measure of human capital (for example, educational attainment), especially at the individual level. Finally, although research suggests that voluntary turnover results in organizational consequences, this study does not present direct evidence in support of this proposition.

\section{Acknowledgement}

Publicly available data for this research was obtained from the State of Oklahoma's Human Capital Management (HCM) division of the Office of Management and Enterprise Services (OMES).

\section{References}

Balfour, D. L., \& Neff, D. M. (1993). Predicting and Managing Turnover in Human Service Agencies: A Case Study of an Organizational Crisis. Public Personnel Management, 22(3), 473-486. https://doi.org/10.1177/009102609302200310

Ban, C., Drahnak-Faller, A., \& Towers, M. (2003). Human Resource Challenges in Human Service and Community Development Organizations: Recruitment and Retention of Professional Staff. Review of Public Personnel Administration, 22(2), 133-153. https://doi.org/10.1177/0734371X03023002004

Becker, G. (1962). Investment in Human Capital: A Theoretical Analysis. Journal of Political Economy, 70(5), 9-49. https://doi.org/10.1086/258724

Berdahl, J. L., \& Moore, C. (2006). Workplace Harassment: Double Jeopardy for Minority Women. Journal of Applied Psychology, 91(2), 426-436. https://doi.org/10.1037/0021-9010.91.2.426

Bertelli, A. M. (2007). Determinants of Bureaucratic Turnover Intention: Evidence from the Department of the Treasury. Journal of Public Administration Research and Theory, 17(2), 
235-258. https://doi.org/10.1093/jopart/mul003

Boone, C., Eckardt, R., Lepak, D., \& Boselie, P. (2018). Integrating Strategic Human Capital and Strategic Human Resource Management. The International Journal of Human Resource Management, 20(1), 34-67. https://doi.org/10.1080/09585192.2017.1380063

Campbell, B. A., Coff, R., \& Kryscynski, D. (2012). Rethinking Sustained Competitive Advantage from Human Capital. Academy of Management Review, 37(3), 376-395. https://doi.org/10.5465/amr.2010.0276

Condrey, S. E. (2010). The Human Capital Phenomenon: Putting People First. Public Administration Review, 70(2), 319-321. https://doi.org/10.1111/j.1540-6210.2010.02140.x

Delery, J. E., \& Roumpi, D. (2017). Strategic Human Resource Management, Human Capital and Competitive Advantage: Is the Field Going in Circles? Human Resource Management Journal, 27(1), 1-21. https://doi.org/10.1111/1748-8583.12137

Flaherty Manchester, C. (2012). General Human Capital and Employee Mobility: How Tuition Reimbursement Increases Retention Through Sorting and Participation. Industrial Labor Relations Review, 65(4), 951-974. https://doi.org/10.1177/001979391206500408

Green, D. D., \& Roberts, G. E. (2012). Impact of Postmodernism on Public Sector Leadership Practices: Federal Government Human Capital Development Implications. Public Personnel Management, 41(1), 79-96. https://doi.org/10.1177/009102601204100105

Grissom, J., Nicholson-Crotty, J., \& Keiser, L. (2012). Does My Boss's Gender Matter? Explaining Job Satisfaction and Employee Turnover in the Public Sector. Journal of Public Administration Research and Theory, 22, 649-673. https://doi.org/10.1093/jopart/mus004

Grissom, J. A., Viano, S. L., \& Selin, J. L. (2015). Understanding Employee Turnover in the Public Sector: Insights from Research on Teacher Mobility. Public Administration Review, 72(2), 241-2511. https://doi.org/10.1111/puar.12435

Hashimoto, M. (1981). Firm-Specific Human Capital as a Shared Investment. The American Economic Review, 71(3), 475-482. https://doi.org/10.1257/aer.91.1.348

Herremans, I. M., \& Isaac, R. G. (2004). Leading the Strategic Development of Intellectual Capital. Leadership \& Organization Development Journal, 142-160. https://doi.org/10.1108/01437730410521822

Hollenbeck, J. R. \& Jamieson, B. B. (2015). Human Capital, Social Capital, and Social Network Analysis: Implications for Strategic Human Resource Management. Academy of Management Perspectives, 29(3), 370-385. https://doi.org/10.5465/amp.2014.0140

Human Capital Management (HCM) division of the Office of Management and Enterprise Services (OMES). (n. d.). Data Definitions. Retrieved from Oklahoma's Official Web Site: https://www.ok.gov/opm/About_HCM/Organization/Workforce_Planning/Workforce_Pl 
an/Data_Definitions.html

Lee, S. (2018). Employee Turnover and Organizational Performance in U.S. Federal Agencies. American Review of Public Administration, 48(6), 522-534. https://doi.org/10.1177/0275074017715322

Lepak, D. \& Snell, S. (1999). The Human Resource Architecture: Toward a Theory of Human Capital Allocation and Development. The Academy of Management Review, 24(1), 31-48. https://doi.org/10.5465/amr.1999.1580439

Lewis, G. B. (1991). Turnover and the Quiet Crisis in the Federal Civil Service. Public Administration Review, 51(2), 145-155. https://doi.org/10.2307/977108

Liebowitz, J. (2011). Addressing the Human Capital Crisis in the Federal Government: A Knowledge Management Perspective. Routledge.

Llorens, J. J., \& Stazyk, E. C. (2011). How Important Are Competitive Wages? Exploring the Impact of Relative Wage Rates on Employee Turnover in State Government. Review of $\begin{array}{llll}\text { Public Personnel } \quad \text { Administration, } & \text { 31(2), }\end{array}$ https://doi.org/10.1177/0734371X10386184

Mawdsley, J. K. \& Somaya, D. (2016). Employee Mobility and Organizational Outcomes: An Integrative Conceptual Framework and Research Agenda. Journal of Management, 42(1), 85-113. https://doi.org/10.1177/0149206315616459

McGregor, E. B. (1991). Strategic Management Human Knowledge, Skills, and Abilities. Jossey-Bass.

Meier, K. \& Hicklin, A. (2008). Employee Turnover and Organizational Performance: Testing a Hypothesis from Classical Public Administration. Journal of Public Administration Research and Theory, 23, 429-456. https://doi.org/10.1093/jopart/mum028

Morris, S. S., Alvarez, S. A., Barney, J. B., \& Molloy, J. C. (2017). Firm-Specific Human Capital Investment as a Signal of General Value: Revisiting Assumptions About Human Capital and How it is Managed. Strategic Management Journal, 38, 912-919. https://doi.org/10.1002/smj.2521

Ndinguri, E., Prieto, L., \& Machtmes, K. (2012). Human Capital Development Dynamics: The Knowledge Based Approach. Academy of Strategic Management Journal, 121-136.

Office of Management and Enterprise Services (OMES) (2017). Merit System of Personnel Administration Rules Title 260: Chapters 25, 30 and 35. State of Oklahoma Human Capital Management Division.

Perry, R. W. (2004). The Relationship of Affective Organizational Commitment with Supervisory Trust. Review of Public Personnel Administration, 24(2), 133-149. https://doi.org/10.1177/0734371X03262452

Plaut, V. C., Thomas, K. M., \& Hebl, M. R. (2014). Race and Ethnicity in the Workplace: Spotlighting the Perspectives of Historically Stigmatized Groups. Cultural Diversity and 
Ethnic Minority Psychology, 20(4), 479-482. https://doi.org/10.1037/a0037544

Rainey, H. G. (2003). Understanding and Managing Public Organizations. San Francisco, CA: John Wiley \& Sons.

Shaw, J. D., Park, T., \& Kim, E. (2013). A Resource-Based Perspective on Human Capital Losses, HRM Investments, and Organizational Performance. Strategic Management Journal, 33, 572-589. https://doi.org/10.1002/smj.2025

Thom, M. \& Reilly, T. (2015). Compensation Benchmarking Practices in Large U.S. Local Governments: Results of a National Survey. Public Personnel Management, 44, 1-16. https://doi.org/10.1177/0091026015586266

Toossi, M. (2016). A Look at the Future of the U.S. Labor Force to 2060. U.S. Bureau of Labor Statistics Spotlight on Statistics, 1-12.

Toossi, M. (2012). Labor Force Projections to 2020: A More Slowly Growing Workforce. U.S. Bureau of Labor Statistics Monthly Labor Review, 43-64.

Wayne, S. J., Liden, R. C., Kraimer, M. L., \& Graf, I. K. (1999). The Role of Human Capital, Motivation and Supervisor Sponsorship in Predicting Career Success. Journal of Organizational Behavior, 20, 577-595. https://doi.org/10.1002/(SICI)1099-1379(199909)20:5\%3C577::AID-JOB958\%3E3.0.C $\mathrm{O} ; 2-0$

Wei, Y. (2015). Do Employees High in General Human Capital Tend to Have Higher Turnover Intention? The Moderating Role of High-Performance HR Practices and P-O Fit. Personnel Review, 44(5), 739-756. https://doi.org/10.1108/PR-07-2013-0137

Wooldridge, J. M. (2009). Introductory Econometrics: A Modern Approach (4th ed.). South-Western Cengage Learning.

Wright, M., Tartari, V., Huang, K. G., Di Lorenzo, F., \& Bercovitz, J. (2018). Knowledge Worker Mobility in Context: Pushing the Boundaries of Theory and Methods. Journal of Management Studies, 55(1), 1-26. https://doi.org/10.1111/joms.12316

\section{Appendix}

Appendix 1. State of Oklahoma Job Categories*

"EEO Job Categories," as used in the context of affirmative action/equal employment opportunity, means the following occupational categories:

(A) Officials and Administrators: Occupations in which employees set broad policies, exercise overall responsibility for execution of these policies, or direct individual departments or special phases of the agency's operations, or provide specialized consultation on a regional, district or area basis.

(B) Professionals: Occupations which require specialized and theoretical knowledge which is 
usually acquired through college training or through work experience and other training which provides comparable knowledge.

(C) Technicians: Occupations which require a combination of basic scientific or technical knowledge and manual skill which can be obtained through specialized post-secondary school education or through equivalent on-the-job training.

(D) Protective Service Workers: Occupations in which workers are entrusted with public safety, security and protection from destructive forces.

(E) Paraprofessionals: Occupations in which workers perform some of the duties of a professional or technician in a supportive role, which usually require less formal training and/or experience normally required for professional or technical status.

(F) Administrative Support (Including Clerical and Sales): Occupations in which workers are responsible for internal and external communication, recording and retrieval of data and/or information and other paperwork required in an office.

(G) Skilled Craft Workers: Occupations in which workers perform jobs which require special manual skill and a thorough and comprehensive knowledge of the processes involved in the work which is acquired through on-the-job training and experience or through apprenticeship or other formal training programs.

(H) Service-Maintenance: Occupations in which workers perform duties which result in or contribute to the comfort, convenience, hygiene or safety of the general public or which contribute to the upkeep and care of buildings, facilities or grounds of public property.

*Job categories provided here are taken directly from the OMES Merit System of Personnel Administration Rules Title 260: Chapters 25, 30 and 35 (see OMES, 2017).

\section{Copyright Disclaimer}

Copyright for this article is retained by the author(s), with first publication rights granted to the journal.

This is an open-access article distributed under the terms and conditions of the Creative Commons Attribution license (http://creativecommons.org/licenses/by/4.0/). 